\title{
PRÁTICAS DE LETRAMENTO E MULTIMODALIDADE: UMA ANÁLISE SOBRE O USO DO GÊNERO “MEME" NA SALA DE AULA
}

\author{
PRACTICES OF LITERACY AND MULTIMODALITY: AN ANALYSIS \\ OF THE USE OF THE "MEME" GENDER IN THE CLASSROOM
}

\author{
Marcos Antônio de Oliveira ${ }^{1}$ \\ Alisson Arlindo da Silva Aquino ${ }^{2}$ \\ Autarquia Educacional de Serra Talhada \\ Daniela Paula Lima Nunes Malta ${ }^{3}$ \\ Universidade Federal de Pernambuco
}

\section{RESUMO}

O trabalho com a multimodalidade e multiletramento se caracteriza como uma ferramenta que viabiliza cada vez mais as práticas na sala de aula que, hoje, tem sido um grande desafio frente às novas tecnologias surgidas ao longo do tempo, possibilitando, dessa forma, o aparecimento de novos gêneros discursivos. As pessoas estão ficando cada vez mais "visuais" e essa comunicação por meio de representações textuais atreladas a imagens, gestos e arranjos não-padrões, chamados de gêneros multimodais, teve um aumento consideravelmente maior no cotidiano das pessoas. $\mathrm{O}$ exemplo mais notório são os chamados "memes", gênero muito difundido nas redes sociais e que se tornou popular diante da sua função de humor e crítica social. Considerando o "meme" como um gênero multimodal, em especial por fazer parte do cotidiano de muitos jovens, este trabalho tem como objetivo mostrar a importância deste gênero como recurso didático a ser trabalhado nas aulas de língua portuguesa do ensino médio enfatizando o desenvolvimento da leitura e interpretação de forma crítica e construtiva. Para identificar o problema alvo da pesquisa foi feita, com uma turma de $2^{\circ}$ ano do ensino médio de uma escola estadual, uma avaliação diagnóstica na forma de questionário, em que se percebeu que os alunos tinham um conhecimento muito inferior ao esperado acerca dos gêneros textuais multimodais, logo em seguida foram elaboradas oficinas didáticas para demonstrar como este gênero poderia contribuir de forma significativa ao aprendizado através de uma prática dinâmica e descontraída, resultando nas produções textuais do referido gênero.

PALAVRAS-CHAVE: letramento; gêneros textuais; gêneros multimodais; "memes".

\begin{abstract}
The work with multimodality and multiliteracy is characterized as a tool that makes more and more the practices in the classroom that, today, has been a great challenge in front of the new technologies that have arisen over time, thus allowing the appearance of New discursive genres. People are becoming more and more "visual" and this communication through textual representations linked to non-standard images, gestures and arrangements, called multimodal genres, has increased considerably in the daily lives of people. The most notorious example is the so-called "memes", a popular genre in social networks that has become popular in the face of its humor and social criticism. Considering the "meme" as a multimodal genre, especially for being part of the daily life of many young people, this work aims to show the importance of this genre

\footnotetext{
${ }^{1}$ Graduado em Letras pela Autarquia Educacional de Serra Talhada (AESET). E-mail: marcosletras@live.com.

${ }^{2}$ Graduado em Letras pela Autarquia Educacional de Serra Talhada (AESET). E-mail: alisson.silva30@hotmail.com.

${ }^{3}$ Mestranda em Linguística pela Universidade Federal de Pernambuco. E-mail: malta_daniela@yahoo.com.br.
} 
as a didactic resource to be worked in the Portuguese language classes of high school emphasizing the development of reading And interpretation in a critical and constructive way. In order to identify the problem of the research, a diagnostic evaluation in the form of a questionnaire was carried out with a second year high school class of a state school, in which it was noticed that the students had a much lower knowledge than expected about the textual genres Multimodal, and then didactic workshops were developed to demonstrate how this genre could contribute significantly to learning through a dynamic and relaxed practice, resulting in the textual productions of this genre.

KEYWORDS: literacy; textual genres; multimodal genres; "memes"

\section{INTRODUÇÃO}

Hoje, o ensino de Língua Portuguesa deve ser pautado na diversidade textual. Segundo Marcuschi (2008), é consenso entre os linguistas que o ensino de língua deve ocorrer através dos textos, sendo essa a orientação central dos Parâmetros Curriculares Nacionais, o que tem se configurado como uma prática comum nas escolas, visto que há muitas formas de se trabalhar com textos em sala de aula.

De acordo com os Parâmetros Curriculares Nacionais da Língua Portuguesa, "cabe à escola viabilizar o acesso do aluno ao universo dos textos que circulam socialmente, ensinar a produzi-los e a interpretá-los" (BRASIL, 1997, p. 26).

O trabalho com os diferentes gêneros textuais em sala de aula visa justamente este aspecto, pois o ensino apenas da gramática por si já não supre a demanda que se tem hoje: de formar cidadãos críticos e capazes de exercer a sua cidadania. Diante disso, a contextualização do ensino contribui para a formação de um aluno que se percebe como protagonista de sua história, capaz de transformar a sua realidade por meio da busca de informação e da reflexão crítica e imaginativa.

Com as inovações tecnológicas têm surgido cada vez mais formas de representação da realidade social, em que se pode destacar o surgimento de novos gêneros discursivos como "tweets", "posts", "chats", "memes”, etc., os chamados gêneros multimodais têm tomado um espaço bastante relevante nesse meio e influenciado cada vez mais as formas de leitura e escrita, isso porque a nossa sociedade está cada vez mais "visual", colaborando com o surgimento cada vez mais frequente desses gêneros que, para Dionísio (2005), se caracterizam por serem gêneros que geralmente aliam uma linguagem visual e verbal, como também diferentes arranjos não-padrões de textos, palavras e gestos, palavras e entonações, etc., resultado da relação entre discurso e inovações tecnológicas.

Considerando o "meme" como um gênero multimodal e em especial por fazer parte do cotidiano de muitos jovens, este trabalho tem como objetivos: a) discutir a importância desse gênero como recurso didático a ser trabalhado nas aulas de língua portuguesa do ensino médio, enfatizando a criticidade no processo de leitura e interpretação; b) identificar a relação desse gênero com outros gêneros multimodais e c) promover o debate em torno do seu uso para um aprendizado significativo.

No âmbito escolar, a prática da leitura é um desafio para professores, que muitas vezes veem nos seus alunos uma grande desmotivação. Partindo desse pressuposto, acredita-se que levar um texto que estabeleça uma relação entre a realidade e a fase em que os alunos se encontram pode ser um fator imprescindível para motivá-los quanto ao interesse pela leitura e suas reflexões.

Logo, este trabalho justifica-se por possibilitar aos alunos do ensino médio um horizonte amplo de conhecimento vinculado à sala de aula, uma vez que eles não têm oportunidade de compreender com profundidade as diversas informações contidas nos muitos "ambientes" do cotidiano nos quais estão inseridos. 
Para identificar o problema alvo da pesquisa foi feita uma avaliação diagnóstica na forma de questionário com uma turma $2^{\circ}$ ano do ensino médio de uma Escola Estadual localizada na cidade de Serra Talhada - PE. Por meio dessa avaliação, percebeu-se que os alunos da referida turma tinham um conhecimento muito inferior ao esperado acerca dos gêneros textuais multimodais, como, por exemplo, a charge, as histórias em quadrinhos (HQ), o cartum, os "memes", etc.. E diante das respostas pessoais, em conjunto com as que abordavam o assunto em questão, notou-se que havia na turma um baixo índice de interesse e de domínio sobre a diversidade dos gêneros e a sua importância no contexto escolar e social. Após a avaliação diagnóstica foram elaboradas oficinas de acordo com os objetivos deste trabalho que seguiu desde aulas expositivas, que abordaram o tema com apresentação de dinâmicas, até as em produções textuais do referido gênero feitas pelos alunos da turma.

\section{Algumas abordagens teóricas acerca de gêneros, letramento e ensino}

As primeiras noções de gênero remontam da Antiguidade Clássica com Platão e Aristóteles, em que se tinha uma noção genérica que dividia os gêneros em apenas três tipos, que eram o lírico, o épico e o dramático, que serviam para a representação ou imitação da realidade da época, chamados de gêneros literários. A questão de gênero era então de preocupação da literatura.

Com o surgimento dos estudos linguísticos - que de início tinha seu enfoque em unidades menores que o texto - houve uma mudança nas discussões acerca de gêneros, ampliando sua noção para além do caráter literário.

No início do século XX, o Formalismo Russo ${ }^{4}$, apropriando-se dos estudos linguísticos de Ferdinand de Saussure, deu uma nova abordagem às discussões sobre gênero. De acordo com Ferreira (2011), os formalistas defendiam o caráter evolutivo dos gêneros e consideravam o seu desenvolvimento como um processo dinâmico, ou seja, uma nova forma de gênero surgiria com o esgotamento de possibilidades do antigo processo de exercer uma determinada função.

$\mathrm{Na}$ segunda metade desse mesmo século, Mikhail Bakhtin (1895-1975) liderou um movimento que deu continuidade à discussão, expandindo essa noção de gênero para além dos estudos literários, afirmando que a utilização da língua deve envolver "todas as esferas da atividade humana" (BAKHTIN, 1997, p. 279).

A língua é efetuada através de enunciados concretos (orais e escritos) que refletem a finalidade e especificidade da esfera social a que pertencem. Bakhtin (1997, p. 301) diz que "para falar, utilizamo-nos sempre dos gêneros do discurso, em outras palavras, todos os nossos enunciados dispõem de uma forma padrão e relativamente estável de estruturação de um todo. Possuímos um rico repertório dos gêneros do discurso orais (e escritos)" (grifo do autor). A riqueza e a variedade desses gêneros seriam infinitas, porquanto a diversidade da atividade humana é inesgotável e o desenvolvimento da própria esfera social que vai ampliando o repertório próprio de gêneros de acordo com sua complexidade.

A perspectiva de Bronckart (2003) sobre gêneros tem proximidade com a de Bakhtin, pois ele considera os gêneros produtos da atividade de linguagem humana e conceituados em função dos seus objetivos, sendo os gêneros considerados sequências "relativamente estáveis" que se moldam de acordo com a atividade linguística e discursiva pertencentes à esfera social na qual os sujeitos estão inseridos.

Para Bronckart,

todo indivíduo de uma determinada comunidade linguística, ao agir com a linguagem, é confrontado permanentemente com um universo de textos pré-existentes organizados em gêneros, que se encontram sempre em um processo de permanente modificação e

\footnotetext{
${ }^{4}$ Influente escola de crítica literária que iniciou uma abordagem linguística da Literatura, um dos principais expoentes foi o crítico literário Victor Chklovsky. Esse pensamento perdurou de 1910 a 1930.
} 
que são em número teoricamente ilimitados (BRONCKART apud MACHADO e CRISTOVÃO, 2006).

Enquanto Bakhtin focou seus estudos nos gêneros do discurso, e estes gêneros configuramse como produtos da interação verbal, Bronckart passou a tomar o texto como objeto de estudo, "na medida em que todo texto se inscreve, necessariamente em um conjunto de textos ou em um gênero" (BRONCKART, 2003, p. 75).

Bentes (2001) ressalta que o surgimento dos estudos sobre o texto constituiu-se um "amplo esforço teórico, com perspectivas e métodos diferenciados, que procura ir além dos limites da frase, que procura reintroduzir, em seu escopo teórico o sujeito e a situação de comunicação" (BENTES, 2001, p. 245).

Para Koch texto é

uma manifestação verbal constituída de elementos linguísticos selecionados e ordenados pelos falantes durante a atividade verbal, de modo a permitir aos parceiros, na interação, não apenas a depreensão de conteúdos semânticos, em decorrência da ativação de processos e estratégias de ordem cognitiva, como também a interação (ou atuação) de acordo com as práticas socioculturais (KOCH apud BENTES, 2001, p. 255).

Nesse entendimento, os discursos se materializam através dos textos que são produtos da atividade humana ligados às nossas necessidades, levando a conclusão de que o processo de comunicação verbal realiza-se através dos gêneros textuais. Comungando com o mesmo pensamento, Marcuschi (2005) diz que

os Gêneros Textuais se configuram como textos sociocomunicativos utilizados no dia-adia. Seguindo esta linha de raciocínio, pode-se dizer que toda comunicação ocorre por meio de gêneros textuais. Assim, toda a postura teórica aqui desenvolvida insere-se nos quadros da hipótese sócio-interativa da língua. É neste contexto que os gêneros textuais se constituem como ações sócio-discursivas para agir sobre o mundo e dizer o mundo, constituindo-o de algum modo (p. 22).

É por meio dos gêneros que os indivíduos se comunicam e interagem. Esses gêneros se encontram em permanente modificação e são eles que garantem a comunicação e a veiculação do conhecimento. À vista disso, é importante ter um domínio cada vez maior sobre essa diversidade de textos para que possa ser promovida a interação e a participação social com mais solidez.

A busca pelo uso de diversas linguagens surge mediante as necessidades de comunicação que o ser humano possui. Para que haja a construção das capacidades comunicativas é necessário que estas se estabeleçam a partir de um sentido contido no enunciado, caso contrário, a comunicação não se concretiza de maneira eficiente.

O processo de letramento, então, surge como base para que a leitura e a escrita tenham uma finalidade social, de forma a atuar diretamente nas habilidades comunicativas do indivíduo. Nele o ensino da língua realiza-se com o intuito de promover algo além da alfabetização.

Soares (2002) considera o letramento como [...] o estado ou condição de quem exerce as práticas sociais de leitura e de escrita, de quem participa de eventos em que a escrita é parte integrante da interação entre pessoas e do processo de interpretação dessa interação - os eventos de letramento (p.145).

Dessa forma, pode-se inferir que o letramento não se trata exclusivamente da prática da leitura e da escrita, e sim de um conjunto de habilidades e conhecimentos múltiplos e individuais de cada pessoa. Tais conhecimentos atuam sob um caráter social, que implica, majoritariamente, em apropriar o indivíduo da língua através da qual se comunica, não pressupondo, necessariamente, recorrer ao uso da norma culta ou das formas tradicionais de ensino.

\footnotetext{
${ }^{5}$ Passou então a ser utilizada a expressão gênero de texto ao invés de gênero do discurso.
} 
O uso dos gêneros, por conseguinte, emerge como suporte para facultar este processo, pois, analisando as suas infinitas possibilidades de se trabalhar, constata-se que o seu uso pode ser facilmente introduzido e/ou adaptado às mais diversas situações comunicativas, podendo levar a resultados de grande expressividade.

As práticas de letramento ${ }^{6}$ efetuadas por meio do uso dos mais diversificados gêneros textuais apresentam-se cada vez mais como alternativa necessária no espaço escolar. No que se refere ao letramento como prática social o conceito proposto por Barton e Hamilton (1998), em uma de suas proposições, diz que as práticas de letramento mudam, e novas práticas são frequentemente adquiridas através de processos de aprendizagem informal e significativa. Nesse contexto, o trabalho com um gênero informal, no caso o "meme", pode trazer um relevante aprendizado ao estimular o aluno a enxergar o seu caráter dinâmico e social.

O estudo realizado dentro do habitual vem se modificando de maneira simbólica e a pedagogia caminhando por novos modelos de interação que têm apresentado resultados bastante significativos. Tal processo faz-se muito pertinente ao analisarmos o quanto pode ser produtiva a associação de diversas técnicas com finalidades em comum, uma vez que estas possibilitam o desenvolvimento das capacidades comunicativas de quem com elas trabalha, pois como ressalta Marcuschi (2001, p. 141), "os manuais escolares precisam contribuir com instrumentos que permitam aos professores um melhor desempenho do seu papel profissional no processo de ensino-aprendizagem".

Com isso, as formas de trabalhá-los percorrem um caminho de amplas possibilidades, que não se restringem a um universo limitado, pautado no que é usado tradicionalmente, haja vista que os gêneros são as ferramentas pelas quais se estabelecem todas as formas de comunicação, é preciso que estes se moldem para que atendam às diversas necessidades que os contextos exigem.

\section{Multiletramentos e multimodalidade: caminhos confluentes}

Segundo Rojo (2012) existe uma necessidade de se incluir no currículo escolar a ampla multiplicidade das novas culturas e textos que surgem no mundo globalizado com o subsídio das novas tecnologias, visto que já estão presentes na vida dos alunos, mas ainda não estão presentes na escola.

Essas novas ferramentas de acesso à comunicação, informação e a multiplicidade de linguagens surgem da necessidade de novas formas de letramentos, denominados multiletramentos, que envolvem tanto aspectos multimodais quanto multiculturais. Além disso, a pedagogia dos multiletramentos, parte da afirmação de que o mundo contemporâneo é caracterizado pela multiplicidade cultural que se expressa e se comunica por meio de textos multissemióticos (impressos ou digitais), ou seja, textos constituídos por meio de uma multiplicidade de linguagens (fotos, vídeos e gráficos, linguagem verbal oral ou escrita, sonoridades) que fazem significar estes textos.

Ao questionar o papel da escola frente aos novos letramentos e ao novo perfil de alunado, os multiletramentos nos instigam a pensar, entre outras coisas, como as novas tecnologias da informação, os hipertextos e hipermídias podem mudar o que se entende na escola por ensino e aprendizagem. Desse modo, a inserção de multiletramentos no ambiente escolar incluiria não apenas o uso das novas ferramentas de comunicação, mas também as práticas de produção e análise crítica de textos multimodais e multiculturais.

Essa pedagogia, segundo Rojo (2012), tem dentre seus princípios básicos, o de formar usuários que tenham competências técnicas e conhecimentos práticos, capazes de criar sentidos e entendendo como os diferentes tipos de texto e de tecnologias operam e ainda, como analistas e

\footnotetext{
${ }^{6}$ Letramento é melhor compreendido como um conjunto de práticas sociais, inferidas a partir de eventos que são mediados por textos escritos, sendo que essas práticas são intencionais, premeditadas, encaixadas em objetivos sociais mais amplos e em práticas culturais historicamente situadas. (Barton e Hamilton, 1998).
} 
críticos, percebam que tudo o que é dito e estudado é fruto de seleção prévia, além de ser um agente transformador, que usa o que foi aprendido.

Com a chegada da Internet aliada às Tecnologias de Informação e Comunicação, a linguagem que até então tomava como ponto de partida a escrita, passou a ser, na contemporaneidade, peça propulsora na interligação do sistema de rede conectada aos meios eletrônicos, ganhando um novo estilo constitutivo marcado por formas híbridas de texto que misturam sons, imagens, palavras (recursos verbais e não-verbais) resultando nos chamados textos multimodais, que de acordo com Mayer (2001) surgiram do advento da tecnologia computacional que permitiu uma explosão na disponibilidade de modos de apresentação visual de materiais, que por consequência causaram uma revolução no cenário da comunicação.

\footnotetext{
Com o advento de novas tecnologias, com muita facilidade se criam novas imagens, novos layouts, bem como se divulgam tais criações para uma ampla audiência. Todos os recursos utilizados na construção dos gêneros textuais exercem uma função retórica na construção de sentido dos textos. Cada vez mais se observa a combinação de material visual com a escrita; vivemos, sem dúvida, numa sociedade cada vez mais visual. Representação e imagens não são meramente formas de expressão para divulgação de informações, ou representações naturais (DIONÍSIO, 2005, p.159-160).
}

Dionísio nos diz que com o advento dessas novas tecnologias nossa sociedade está cada vez mais visual e define os textos multimodais como "textos especialmente construídos que revelam as nossas relações com a sociedade e com o que a sociedade representa" (idem).

Compreende-se, nesse sentido, que o que antes era feito mecanicamente, através de simples decodificação de signos linguísticos ou fluência na oralidade foi ressignificado pela mediação de ferramentas digitais no uso da língua. Diante dessas transfigurações da noção do objeto texto, observa-se que houve mudanças também na prática de leitura e no perfil do leitor atual, e de sobremaneira do leitor-navegador, que usa a internet como fonte de informação, mantendo contato com os mais variados gêneros digitais.

De acordo com os atuais Parâmetros Curriculares Nacionais do Ensino Médio (PCNEM),

o ensino de Língua Portuguesa, hoje, busca desenvolver no aluno seu potencial crítico, sua percepção das múltiplas possibilidades de expressão linguística, sua capacitação como leitor efetivo dos mais diversos textos representativos de nossa cultura. Para além da memorização mecânica de regras gramaticais ou das características de determinado movimento literário, o aluno deve ter meios para ampliar e articular conhecimentos e competências que possam ser mobilizadas nas inúmeras situações de uso da língua com que se depara, na família, entre amigos, na escola, no mundo do trabalho (BRASIL, 2002, p.55).

A multimodalidade também é enfatizada nas Orientações Curriculares para o Ensino Médio (BRASIL, 2006, p. 25), quando afirma que nós "vivemos em um mundo culturalmente organizado por múltiplos sistemas semióticos - linguagens verbal e não-verbal - resultado de trabalho humano que foi sedimentado numa relação de convencionalidade".

É possível inferir que nas orientações curriculares oficiais, as práticas de linguagem no espaço escolar devem ser focadas em letramentos múltiplos que se constroem de forma multissemiótica e híbrida.

Atualmente, os alunos estão em constante contato com recursos tecnológicos, uma série de instrumentos e de novas tecnologias, e isso exige uma transformação das práticas de letramento para que percebam essas linguagens de um modo diferenciado e possam utilizá-las.

Com o propósito da formação de novos leitores e autores, pensando nas novas formas de autoria que surge dentro do ambiente digital através de textos multimodais, conforme Fonte e Caiado 


\begin{abstract}
a percepção contemporânea é a de que práticas digitais repercutem em letramentos múltiplos, uma vez que possibilitam que sujeitos conectados - ávidos por: "curtir", "comentar", "compartilhar", ávidos por interação e que possuem dispositivos tecnológicos intra e extramuros escolares - tornem-se letrados digitais, favorecendo práticas de leitura e escrita na rede (2015, p. 41).
\end{abstract}

Dessa maneira, considerando os variados recursos semióticos relacionados ao contexto contemporâneo, surge nesse cenário a inserção do letramento multimodal que tem por objetivo incorporar e reunir os saberes necessários para lidar com esses diversos modos semióticos, combinando esses recursos, para usá-los da maneira mais adequada a fim de alcançar os propósitos definidos em cada prática social.

Como propõe Herbele (2012, p. 95), "o conceito de multiletramento deve incluir a multiplicidade de discursos, novas tecnologias de comunicação e multimídia em gêneros diversos". Levando em consideração o prefixo "multi" utilizado nos termos, pode-se então concluir que o multiletramento tem uma relação intrínseca com a multimodalidade, pois esta engloba uma gama de práticas de atividades de leitura e escrita de textos multimodais que levam em consideração o uso de diferentes sistemas semióticos. Com isso, configura-se a confluência temática e o entrelaçamento teórico, que emergem a partir da conceituação e sua mobilidade pedagógica.

\title{
3. Os gêneros multimodais na sala de aula
}

Como visto, as práticas de letramento estão cada vez mais cercadas por desafios constantes com a chegada da chamada era digital e do desenvolvimento da tecnologia.

Os Parâmetros Curriculares Nacionais para o Ensino Médio ( $\mathrm{PCN}+$ ) enfatizam que "a aquisição paulatina do conceito amplo (linguagem) e do mais específico (língua) passa pela compreensão da diversidade textual [...]" (BRASIL, 2002, p. 94). Partindo da premissa de que todos os gêneros textuais escritos e falados são multimodais, significa dizer então que os gêneros multimodais estão mais que presentes na sala de aula do que se imagina.

É importante mencionar que o ensino pautado nos textos multimodais possibilita ao aluno compreender essa diversidade encontrada nos mais diferentes meios de comunicação presentes no cotidiano, sendo, diante disso, cada vez mais "frequente a preocupação dos professores em inserir gêneros textuais diversos e recursos tecnológicos da sociedade moderna nas atividades realizadas em sala de aula" (DIONÍSIO, 2005, p. 140). E essa preocupação é norteada pelo fato de que "todo professor tem convicção de que imagens ajudam a aprendizagem, quer seja como recurso para prender a atenção dos alunos, quer seja como portador de informação complementar ao texto verbal" (idem, p. 141, grifo da autora).

Mayer (2001) apud Dionísio (2005) diz que "os alunos aprendem melhor através de palavras e imagens que de palavras apenas" (p. 141) constate-se então que quando procuramos uma metodologia que abrange palavras e imagens, aliamos a ludicidade à interação e com isso despertamos um maior interesse nos alunos em aprender.

Apesar das perspectivas teóricas apontarem a importância de se trabalhar com tais gêneros ligados às inovações tecnológicas, ainda não se vê efetivamente essa prática nas escolas e isso se dá ao fato das inúmeras limitações que existem, seja por falta de recursos didáticos e tecnológicos na escola, seja pela falta de capacitação do professor ou até mesmo pelo interesse dos alunos.

Citando Lemke, Dionísio também aponta para a importância justamente de se haver uma compreensão por parte tanto de professores como de alunos dos aspectos que cercam as práticas de multiletramentos e gêneros multimodais, "o que eles são, para que eles são usados, que recursos empregam, como eles podem ser integrados um ao outro, como eles são tipicamente formatados, quais são seus valores e limitações" (LEMKE apud, 2005, p. 140).

Logo, pode-se notar que a multimodalidade está presente na sala de aula mesmo que muitas vezes, professores e alunos não compreendam a conjuntura desses textos e os diferentes aspectos 
dos gêneros multimodais, e por isso a dificuldade de se trabalhar com esses novos gêneros frutos das inovações tecnológicas continua sendo um grande desafio.

Por isso, dentre as concepções de letramento, tem ganhado força o chamado "letramento digital", que se torna uma ferramenta indispensável na apropriação do conhecimento, ele parte do conceito de letramento, que vimos na seção anterior anterior, e "compreende tanto a apropriação das tecnologias - como usar o mouse, o teclado, a barra de rolagem, ligar e desligar os dispositivos - quanto o desenvolvimento de habilidades para produzir associações e compreensões nos espaços multimidiáticos" (ZACHARIAS, 2016, p. 21). A mesma autora continua dizendo que "se pretendemos incluir o letramento digital nas escolas, devemos somar às práticas habituais de leitura aos novos comportamentos dos leitores, assim como utilizar os textos de diferentes mídias, em seus suportes reais" (p. 24).

Zacharias (2016) ainda afirma que essa expansão da tecnologia acarreta transformações na vida em sociedade e isso vem alterando a relação do indivíduo com os textos, que são compartilhados simultaneamente com a possibilidade de selecionar o conteúdo de acordo com os interesses. Diante disso, compreende-se que o letramento digital se torna por si necessário ao desenvolvimento do conhecimento, pois o que mais se vê no cotidiano dos alunos são essas modalidades de gêneros.

O uso destes gêneros faz com que as aulas se tornem mais dinâmicas, contribuindo para que os alunos enxerguem nos "tweets", nos "blogs", nos "memes" e nos mais diversos textos de caráter digital novas formas de aprendizado e construção de conhecimento.

As Orientações Curriculares para o Ensino Médio (2006) orientam, nesse sentido, quando diz que o ensino da leitura e da escrita deve ser concebido como ferramenta de "empoderamento e inclusão social" e que a escola deve

criar condições para que os alunos construam sua autonomia nas sociedades contemporâneas - tecnologicamente complexas e globalizadas - [...] isso significa dizer que a escola que se pretende efetivamente inclusiva e aberta à diversidade não pode aterse ao letramento da letra, mas deve, isso sim, abrir-se aos múltiplos letramentos, que, envolvendo uma enorme variação de mídias, constroem-se de forma multissemiótica e hibrida[...] (BRASIL, 2006, p. 29).

Pode-se dizer, então, que o uso dos gêneros multimodais na sala de aula surge como proposta para o cumprimento do que se pede nas orientações curriculares, possibilitando que o aluno desenvolva as competências exigíveis na sociedade contemporânea e no meio em que ele está inserido, auxiliando-o na sua formação como sujeito capaz de exercer a sua cidadania.

\subsection{O gênero multimodal "meme"}

É notório que a comunicação na internet acabou criando novos gêneros e alterando outros, comprovando que eles estão a serviço dos falantes e às necessidades de seu tempo.

Se antes enviávamos cartas, hoje enviamos e-mail, que nada mais é do que uma adaptação virtual que dispensa o papel e a caneta. Se em um passado não muito distante enviávamos mensagens de celular, hoje utilizamos as redes sociais para deixar um recado para nossos amigos. Diante dessa dinâmica, percebemos o surgimento de novos gêneros textuais, dentre eles os gêneros digitais que emanam principalmente dentro da web.

Sabe-se que as redes sociais têm ganhado espaço considerável no que tange à socialização múltipla entre pares diversos que propiciam divulgação de informações, compartilhamento de dados informativos, maior facilidade de criação de conteúdos online e a partilha destes na rede tem ganhado destaque entre os jovens, que fazem uso recorrente das redes sociais de um gênero textual digital e multimodal que se tornou bem recorrente: o "meme". 
O termo "meme" foi criado pelo biólogo britânico Richard Dawkins em 1976 no seu livro "O gene egoísta" em que ele, um dos principais cientistas que estuda a evolução das espécies, explica a origem da expressão "meme", ressaltando em sua obra que

precisamos de um nome para o novo replicador, um substantivo que transmita a ideia de uma unidade de transmissão cultural, ou uma unidade de imitação. "Mimeme" provém de uma raiz grega adequada, mas quero um monossílabo que soe um pouco como "gene". Espero que meus amigos helenistas me perdoem se eu abreviar mimeme para meme. Se servir como consolo, pode-se, alternativamente, pensar que a palavra está relacionada à "memória", ou à palavra francesa même (DAWKINS, 2007, p.112).

Com isso, o autor popularizou a ideia de que a seleção natural acontece a partir dos genes. Eles "buscam" a sobrevivência, por meio de corpos capazes de sobreviver e de se reproduzir (para replicar os genes). O livro, segundo Dawkins, vem com a proposta de que a cultura também se espalha como os genes. O "meme" é o equivalente cultural do gene, a unidade básica de transmissão cultural que se dá por meio da imitação.

Para Blackmore (2000, p. 65), “os 'memes' são histórias, canções, hábitos, habilidades, invenções e maneiras de fazer coisas que copiamos de uma pessoa para outra através da imitação". Ainda segundo essa autora, "os memes têm sido (e são) uma força poderosa que molda nossa evolução cultural e biológica” (idem).

No espaço cibernético, os usuários começaram a utilizar a palavra "meme" para se referir principalmente a comentários, postagens de fotos, vídeos, paródias que são comumente relacionados a notícias do cotidiano provenientes, em grande parte, de outros canais midiáticos, sendo esses a televisão, os jornais impressos e o rádio, ou seja, a tudo que se propaga, ou mesmo se espalha aleatoriamente na grande rede, em especial fragmentos com algum conteúdo humorístico.

Shifman (2014) salienta, assim como Blackmore (2000) - ao aferir ao "meme" um caráter idealista - que o "meme" de internet é uma ideia que está midiatizada através de uma imagem, texto ou som, com a característica de rápida difusão e manipulação por parte de atores sociais atuantes enquanto internautas na rede. Assim, no "meme" de internet não é a imagem, vídeo, texto que é replicado por diversas vezes pelas pessoas na rede, com modificações pessoais de acordo com seu próprio gosto ou intenção, mas sim a ideia que está por traz daquela imagem.

É interessante, contudo, observar que através da cibercultura, aspectos linguísticos, discursivos e sociais têm se materializado em diversas interações multimidiáticas que colocam em evidência o papel da tecnologia como meio de gerar novas formas de comunicação, significação e produção de cultura na pós-modernidade.

\subsection{Uma análise sobre o uso do gênero "meme" no ensino médio}

No entendimento de Marcuschi (2010, p. 15), os gêneros digitais são "os gêneros textuais que estão emergindo no contexto da tecnologia digital em ambientes virtuais". O autor aponta que os gêneros presentes no meio digital possuem características semelhantes aos gêneros textuais já consolidados no meio impresso.

Lidar com alunos na Era Digital pressupõe pensar em meios de agregar as práticas dos professores às novas condições que o aluno da era digital está inserido, levando em conta às novas ferramentas e linguagens proliferadas no mundo cibernético, ressignificando o que se entende como o ato de ensinar e aprender.

Nessa Era em que gêneros digitais, sobretudo o "meme", se fazem tão presentes no círculo social dos estudantes, em especial do ensino médio, cabe ao professor valer-se das suas potencialidades enquanto elemento multímodo, capaz de auxiliar no desenvolvimento das competências linguístico-discursivas de educandos em aulas de língua portuguesa no ensino médio. 
No que diz respeito à produção textual, que muitas vezes é tido como algo trabalhoso para muitos alunos, a inserção do gênero "meme" acaba sendo um ótimo atrativo para os estudantes, pois uma simples frase feita na forma de um "meme" prende mais atenção e abre caminho para o conteúdo desejado, seja de análise linguística ou de compreensão textual.

Competiria ao professor, desse modo, utilizar este componente "mêmico" com o intuito de levar o aluno a reconhecer recursos verbais e não verbais utilizados; relacionar opiniões, temas, assuntos e recursos linguísticos; deduzir quais são os objetivos de seu produtor e quem é seu público alvo (através da análise dos procedimentos argumentativos utilizados) e reconhecer no texto estratégias argumentativas empregadas para o convencimento do público.

Como forma de aplicação, o professor, de sua parte, pode produzir "memes" relacionados ao conteúdo trabalhado ou também pode pedir para que os alunos o façam, explorando assim seus componentes linguísticos tomando como suporte, por exemplo, o "meme" de uma página popular do Facebook: "Bode Gaiato":

Figura 1: "meme" produzido pela página "Bode Gaiato" do Facebook, relatando situações do cotidiano.
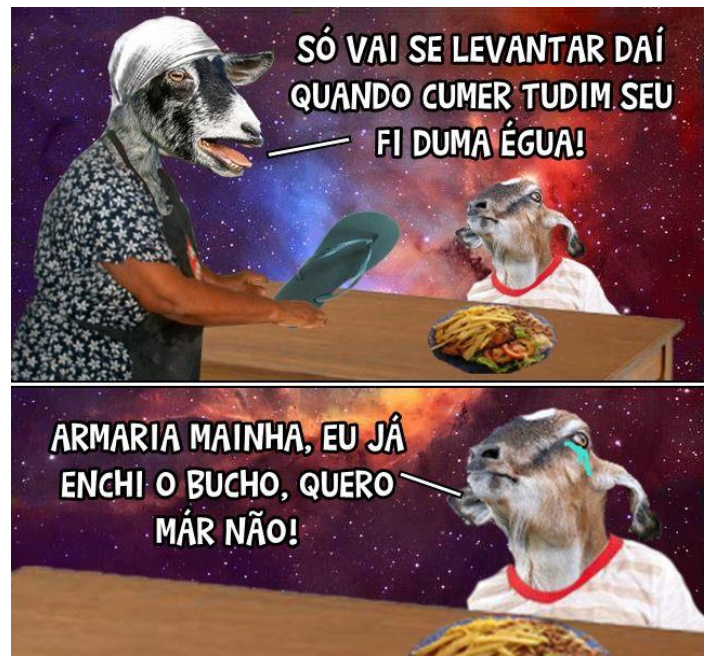

Figura 2: "meme" da página "Bode Gaiato" fazendo uma alusão à aplicação da prova do ENEM.

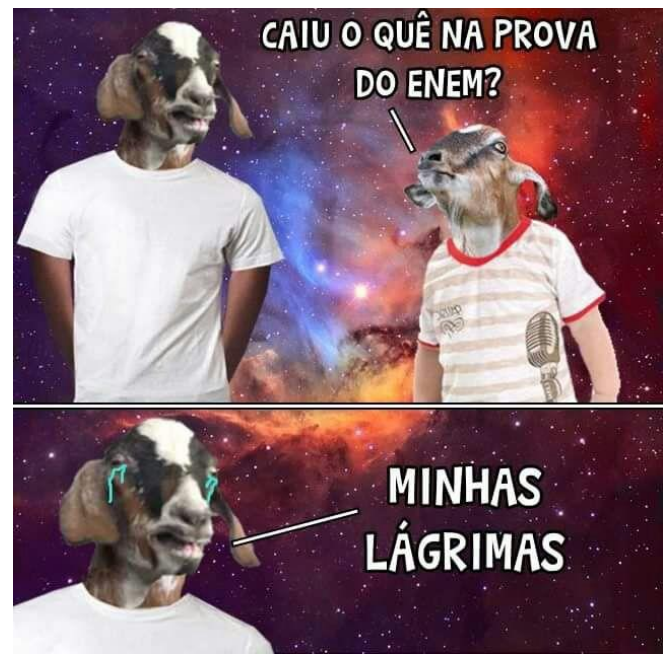

Fonte: https://www.facebook.com/BodeGaiato/?fref=ts

Como sugestão, poderia o professor de língua portuguesa do ensino médio, a partir da análise dos "memes" (figura 1 e 2) juntamente com seus alunos, identificar as marcas linguísticas que singularizam as variedades linguísticas sociais, regionais e de registro, além de também relacionar as variedades linguísticas a situações específicas de uso social e levar os alunos a uma reflexão sobre os usos da norma padrão e coloquial nas diferentes situações de comunicação, como também fazer com o que o aluno reflita o teor crítico que há nos textos, já que esse gênero se assemelha à charge e ao cartum ora enfatizando situações atemporais do cotidiano das pessoas, ora apresentando situações que refletem a atualidade e acontecimentos que estão sendo debatidos nos mais diversos setores da sociedade.

Diante do exposto, percebemos que o "meme" pode ser considerado um recurso eficaz na educação, um campo rico e possível de ser explorado. A sua estrutura dinamiza a didática do conhecimento e, se bem trabalhada, garante ao aluno a noção de gênero textual, como também o desenvolvimento de sua capacidade interpretativa que será acompanhada da linguagem não-verbal, a imagética. 


\section{Um relato de experiência em sala de aula}

O ensino ancorado nos gêneros textuais hoje é uma realidade na sala de aula, fruto das novas concepções de ensino de Língua Portuguesa. Para tanto, se faz necessário agora relatar como essa experiência é de grande valia para os alunos.

Sendo o nosso trabalho pautado nessas novas concepções, este tópico tem como foco demonstrar os resultados obtidos em sala de aula e nossa experiência com essa nova abordagem de ensino, mostrando como o gênero textual tão presente no cotidiano pode colaborar para o aprendizado dos alunos.

\subsection{Observação, diagnose da turma e aplicação das oficinas}

Para a aplicação do projeto, inicialmente, houve um período de observação da turma e, logo em seguida, foi aplicado um questionário a respeito das aulas de Língua Portuguesa e acerca do tema que iríamos trabalhar, que funcionou como sondagem para que fossem constatadas as dificuldades e interesses dos alunos.

Após a aplicação, pontuamos estes aspectos sobre a turma:

\section{Resultado da Avaliação Diagnóstica feita no $2^{\circ}$ Ano do Ensino Médio}

\begin{tabular}{|c|c|c|}
\hline Pontos positivos & Pontos negativos & Características gerais \\
\hline $\begin{array}{l}\text { - Interesse pelo tema; } \\
\text { - Bom comportamento; } \\
\text { - Poucos erros ortográficos; } \\
\text { - Interesse por métodos } \\
\text { atrativos e diferentes nas } \\
\text { aulas de Português; } \\
\text { - Domínio básico sobre o } \\
\text { assunto abordado; } \\
\text { - Todos os alunos presentes } \\
\text { se propuseram a responder } \\
\text { a avaliação. } \\
\text { - } 18 \text { dos } 27 \text { alunos disseram } \\
\text { que tem o hábito de ler. }\end{array}$ & $\begin{array}{l}\text { - Respostas curtas e sem } \\
\text { justificativas; } \\
\text { - Uso do “internetês" nas } \\
\text { respostas; } \\
\text { - Incoerências; } \\
\text { - Dificuldade em distinguir um } \\
\text { gênero de outro. }\end{array}$ & $\begin{array}{l}\text { - Turma com } 28 \text { alunos; } \\
\text { - Grande parte mora na } \\
\text { zona rural; } \\
\text { - Grande parte trabalha; } \\
\text { - Faixa etária varia entre } 15 \text { a } \\
27 \text { anos; } \\
\text { - Grande maioria usa a } \\
\text { internet, apenas } 2 \text { alunos } \\
\text { dos } 27 \text { informaram que não } \\
\text { tem acesso nenhum à rede; } \\
\text { - A média de tempo gasto, } \\
\text { com internet é } 2 \text { h30min por } \\
\text { dia. }\end{array}$ \\
\hline
\end{tabular}

Fonte: os autores

Tendo em mãos os pontos positivos e negativos, tentamos aproveitar ambos da melhor forma e desenvolver a intervenção, de maneira a aproveitar os positivos e suprir as necessidades causadas pelos negativos.

Dada as constatações acima, demos continuidade à ideia de trabalhar a partir dos gêneros multimodais, e dentro desses gêneros, optamos pelo uso do "meme", que constitui um cenário em que alunos dessa faixa etária têm bastante contato. Isso propicia a motivação do aluno, ao mesmo tempo em que ele se apropria de um gênero que faz parte do seu cotidiano e que contribui com as suas capacidades interpretativas, comunicativas e de produção.

Partimos então para a aplicação das oficinas:

Na primeira oficina foi explicado à turma o motivo pelo qual estaríamos abordando o gênero textual "meme" e o porquê de termos escolhido este gênero. Expomos à turma a necessidade de viabilizar a interação e a dinamicidade das aulas para despertar um maior interesse, já que é evidente que este gênero está muito presente no dia a dia dos estudantes nas redes sociais, como foi constatado através da avaliação diagnóstica realizada. 
Antes de adentrar aos conceitos de gêneros textuais, foram apresentadas à turma as funções da linguagem, dentre elas, que a linguagem é uma das formas de apreensão e de comunicação das coisas do mundo e que o ser humano, ao viver em conjunto, utiliza vários códigos para representar o que pensa, o que sente, o que quer, além de ser um elemento fundamental para estabelecermos comunicação com outras pessoas. Explicamos também a diferença entre linguagem verbal e não verbal. Introduzindo a parte dos gêneros textuais, discutimos com os alunos sua conceituação e dicotomia em relação ao tipo textual cujo entendimento é o de que toda comunicação se dá por meio de gêneros textuais.

$\mathrm{Na}$ segunda oficina apresentamos a conceituação do gênero "meme" aos alunos. No primeiro momento, para demonstrar o efeito que o "meme" causa, realizamos com os alunos uma gincana chamada "telefone sem fio", em que organizamos alguns participantes um ao lado do outro numa fila sendo contada uma história ao ouvido de cada um em voz baixa, do primeiro até o último da fila que disse em voz alta a mensagem que recebeu. Nessa dinâmica, a mensagem muitas vezes chega dessemelhante à original, mas sempre permanece a essência, demonstrando, assim, o que funciona com o "meme". Em seguida, por meio de slides, exploramos o conceito da palavra "meme", mostrando as semelhanças e diferenças entre a charge, o "cartum", histórias em quadrinhos já que ambos são gêneros multimodais e que todos, com exceção do "meme", são bem conhecidos por seu uso na escola, principalmente em livros didáticos.

Explicitamos que na internet o "meme" é usado para se referir a algo que se espalha na rede, quase sempre apresentado em fragmento ou conteúdo humorístico. Além disso, foi feita com a turma uma atividade de análise do "meme", reconhecendo os recursos verbais e não verbais utilizados, os pressupostos e subentendidos no texto, além de discussões sobre coloquialismos presentes em alguns "memes" analisados em sala de aula.

$\mathrm{Na}$ terceira oficina os alunos foram convidados a criar o seu próprio "meme". Essa atividade foi sugerida através de um "meme" que elaboramos para elucidar a nossa proposta:

\section{Figura 3}

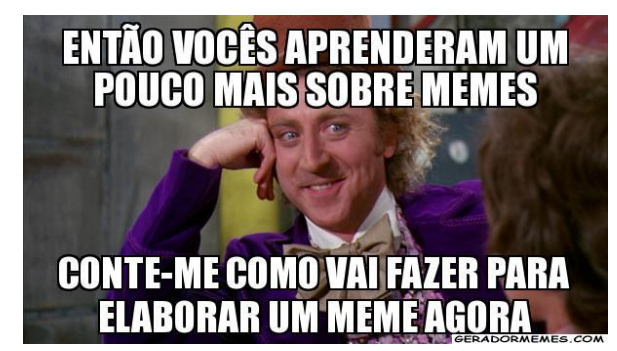

Fonte: Elaboração dos autores

\subsection{Avaliação dos resultados}

Tomando como partida as duas primeiras oficinas e as atividades de sala, a turma foi dividida em grupos de três alunos para realizar suas produções. Cada grupo recebeu uma atividade impressa contendo três imagens com balões, a proposta foi que cada grupo de acordo com sua imaginação e com as sugestões das aulas ministradas sobre "meme" pudesse fazer suas criações do gênero, as atividades foram feitas em papel porque infelizmente não tivemos acesso aos laboratórios de informática para que eles pudessem desenvolver os seus trabalhos no computador. Seguem algumas dessas produções:

Figura 4: representações de "meme" feita pelos alunos

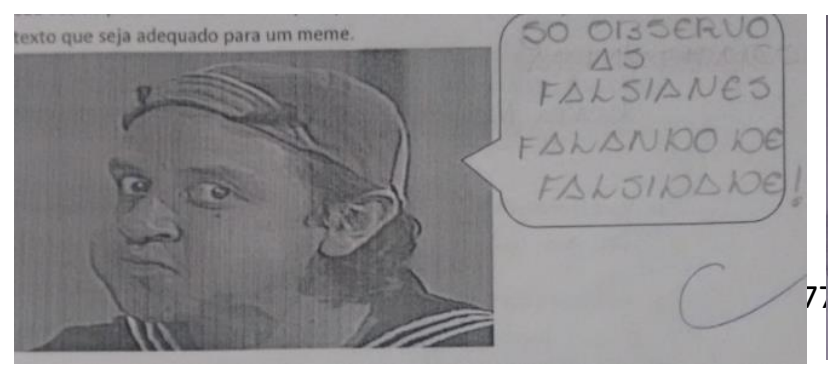

Figura 5: representações de "meme" feita pelos alunos

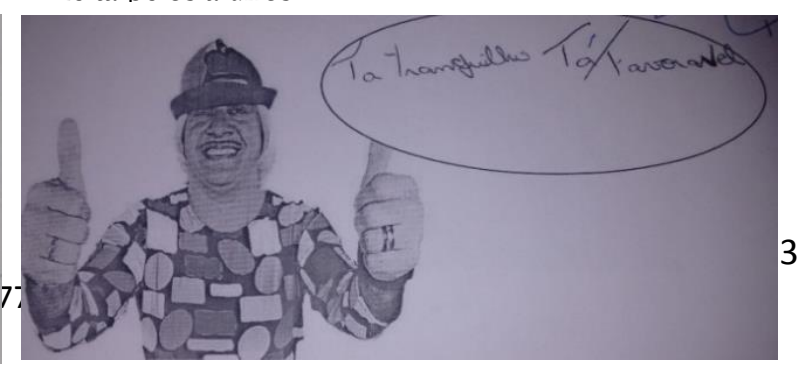


Fonte: os autores

Nas produções acima pudemos constatar a criatividade dos alunos em relatar questões que eles vivem no dia-a-dia, representando a proposta dos "memes", que é, na maioria das vezes, utilizado para retratar as mais variadas situações que acontecem no cotidiano das pessoas, como diz Blackmore (2000), os "memes" são hábitos e maneiras de fazer as coisas que copiamos de uma pessoa por meio da imitação, essas maneiras se traduzem na realidade do aluno que replica bordões criados na internet para adequá-los a sua realidade, sendo que estes, geralmente, são uma ideia midiatizada a partir de uma imagem (Shifman, 2014) ligada, na maioria das vezes, à figuras de personagens que possuem certa notoriedade, como é observado nas imagens acima e analisadas a seguir: na figura 4, o aluno escreveu: "só observo as 'falsianes' falando de falsidade", em que se percebe o neologismo "falsiane", termo popularizado nas redes sociais e usado para se referir a alguém que finge ser amiga, mas que não age como tal, o que ratifica a influência da internet no cotidiano dos alunos.

$\mathrm{Na}$ figura 5 foi escrito “tá tranquilo, tá favorável”, em que o aluno faz uso de um bordão popularizado por um vídeo clipe publicado na internet. É interessante observar que o aluno faz uso da norma não padrão da língua reduzindo a forma "está" do verbo para a forma "tá", muito utilizada nas redes sociais, devido ao dinamismo exigido pela internet, outra questão importante a ser ressaltada é a leitura feita pelo aluno da imagem do humorista Tiririca, que faz uso de um gesto muito comum entre os brasileiros (o polegar para cima) para indicar aprovação, no caso, um duplo polegar.

Isso mostra o caráter social e dinâmico dos "memes": a informalidade como característica e a criação de termos que se propagam e se popularizam facilmente entre as pessoas, que passam a replicar, entre eles, o conteúdo. Reforçando a ideia originalmente criada por Dawkins (2007), que o "meme" é o equivalente cultural do "gene" que se propaga por meio da imitação.

Figura 6: representações de "meme" feita pelos alunos

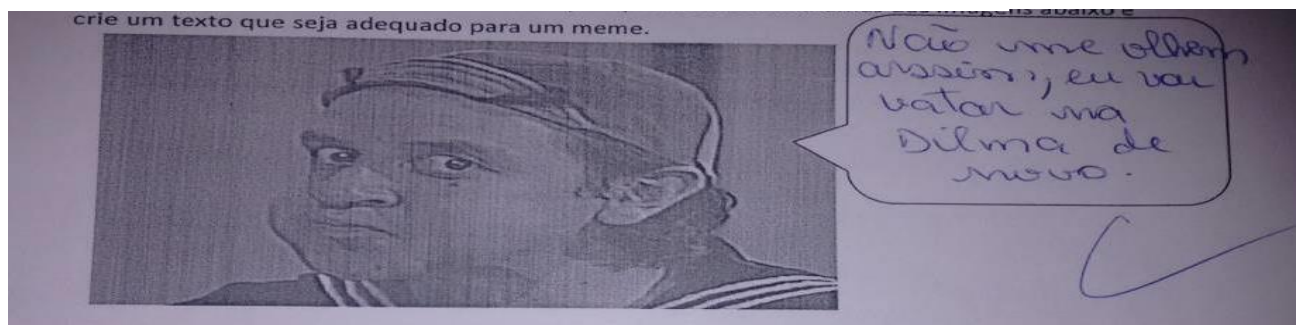

Figura 7: representações de "meme" feita pelos alunos

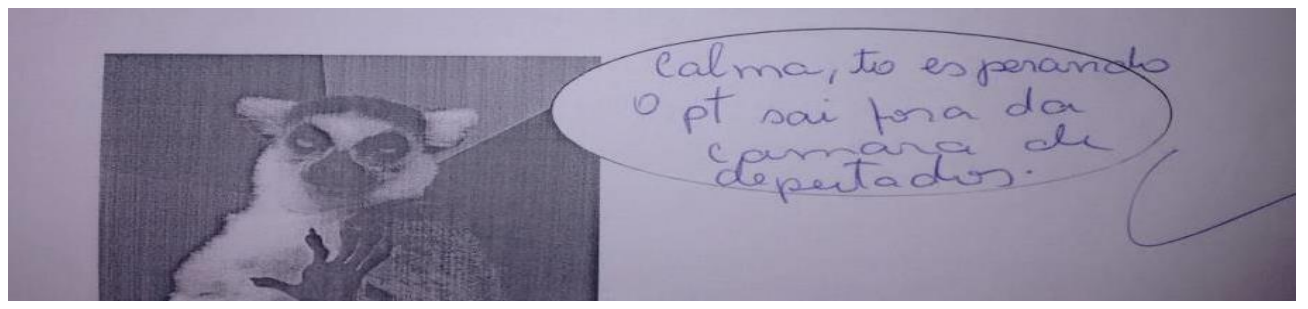

Fonte: os autores

Nas imagens acima podemos observar o caráter ideológico que pode ter o "meme" também muito utilizado para propagar ideias de caráter politico-partidário, e é o que vemos sempre nas redes sociais, cada grupo politico cria seus "memes" para "propagandear" suas ideias e a de seus partidos. No tocante aos alunos, de uma forma simples, eles retratam suas preferências partidárias. 
Na figura 6, o aluno deixou transparecer o seu "lado" político com a frase: "não me olhem assim, eu vou votar na Dilma de novo", típico também dos "memes", pois eles não só representam fatos corriqueiros do dia-a-dia, como também são utilizados constantemente como ferramenta crítica e de expressão do pensamento.

Na figura 7 aluno escreveu: "Calma, to esperando o PT 'sai' fora da câmara de deputados". O que expressa a forma ideológica e discursiva do estudante, que se mostra contrário à presença de políticos filiados ao PT na Câmara dos Deputados. Mostrando o poder que os "memes" tem para moldar o pensamento (Blackmore, 2000) e de passar informações que contribuem para a formação de opinião e construção do pensamento crítico.

Vimos então que é possível aliar a ludicidade ao ensino, fazendo com que o aluno pratique a sua criatividade, auxiliando no processo de aprendizado.

Diante dos exemplos aqui apresentados é possível compreender que os "memes" podem até, para alguns, parecer ingênuo, mas o que há por trás das suas produções reflete tanto o pensamento dos alunos como também, por meio destes, podem expressar suas opiniões.

\section{CONSIDERAÇÕES FINAIS}

O presente trabalho teve como propósito mostrar a contribuição que o gênero multimodal "meme" pode trazer para as aulas de Língua Portuguesa do ensino médio.

Tentamos alcançar com a intervenção em sala de aula, os seguintes objetivos: a) Identificar a relação do "meme" com outros gêneros multimodais no ensino de língua portuguesa; b) Promover o debate em torno do uso do gênero "meme" no ensino de Língua Portuguesa. c) Demonstrar o uso do gênero "meme" como recurso didático-pedagógico para o aprendizado em sala de aula.

Para proporcionar aos alunos uma tentativa de se trabalhar com um gênero diferenciado, aplicamos oficinas e com isso, percebemos que essa proposta foi uma experiência diferente para eles, mesmo não dispondo de tantos recursos a nosso favor, pois o laboratório de informática não estava disponível para que eles fizessem suas produções no computador. Mesmo assim, as produções em sala de aula surtiram o efeito desejado. Os alunos usaram a imaginação e produziram diferentes "memes" inspirados em outros que eles já tinham visto ou de situações do seu cotidiano e até mesmo de expressão de seu pensamento político/ideológico.

Concluímos que, como há ainda poucas discussões a respeito, este pode contribuir para uma maior discussão acerca dessas novas ferramentas que estão sendo utilizadas com grande frequência na atualidade e que muitas vezes deixamos de lado por acreditar que elas não trarão algo significativo para a prática pedagógica. Enfatizamos também que este foi o primeiro trabalho que abordou a Multimodalidade como tema no curso de Letras da Instituição.

De acordo com a experiência vivenciada em sala de aula, deixamos como sugestão para o professor utilizar este componente "mêmico" com o intuito de levar o aluno a reconhecer recursos verbais e não verbais utilizados; relacionar opiniões, temas, assuntos e recursos linguísticos; deduzir quais são os objetivos de seu produtor e quem é seu público alvo (através da análise dos procedimentos argumentativos utilizados) e reconhecer no texto estratégias argumentativas empregadas para o convencimento do público.

Podemos então dizer que essa experiência foi bastante válida para nós como docentes, bem como para os alunos que conseguiram compreender e assimilar a nossa proposta.

\section{REFERÊNCIAS BIBLIOGRÁFICAS}

BAKHTIN, M. Estética da criação verbal. $3^{a}$ ed. São Paulo: Martins Fontes, 2007.

BLACKMORE, S. The Meme Machine. Oxford: Oxford University Press, 2000. 
BARTON D.; HAMILTON, M. Local literacies. Londres and Nova Iorque: Routledge, 1998.

BENTES, A. C., Linguística Textual. In: MUSSALIM, F.; BENTES A. C. (Orgs.). Introdução à Linguística: domínios e fronteiras v. 1. São Paulo: Cortez, 2001. p. 245-285.

BRASIL. Secretaria de Educação Fundamental. Parâmetros Curriculares Nacionais: Língua Portuguesa. Brasília: Ministério da Educação, 1997.

PCN + Ensino Médio: orientações educacionais complementares aos Parâmetros Curriculares na área de Linguagens, Códigos e suas Tecnologias. Brasília: Ministério da Educação, Secretaria da Educação Média e Tecnológica, 2002.

Orientações Curriculares para o Ensino Médio. Vol 1: Linguagens, códigos e suas tecnologias: Brasilia: MEC, SEB, 2006.

BRONCKART, J. P. Atividade de linguagem, textos e discursos: por um interacionismo sóciodiscursivo. EDUC-São Paulo: PUC, 2003.

DAWKINS, R. O Gene Egoísta. Tradução de Rejane Rubino. São Paulo. Companhia das Letras. 2007.

DIONISIO, A. P. Gêneros multimodais e multiletramento. In: KARWOSKI, A. M.;

GAYDECZKA, B.; BRITO, K. S. (Orgs.). Gêneros textuais: reflexões e ensino. Palmas e união da Vitoria, PR: Kaygangue, 2005.

FERREIRA, M. A. V. Estudo dos gêneros: uma perspectiva evolutiva. Diálogo e interação. Volume 5 (2011) (revista eletrônica) disponível em: <HTTP://www.faccrei.edu.br/dialogoeinteracao> acesso em: Out/ 2016.

FONTE, R. F. L.; CAIADO, R. Multimodalidade e tecnologia móvel digital: uma relação entre texto e texto verbal na produção de sentindo In: ACIOLI, M. D. et al.(Orgs.). Linguagem: entre o sistema, o texto e o discurso. $1^{\mathrm{a}}$ ed - Curitiba: CRV, 2015.

HEBERLE, V. M. Multimodalidade e multiletramento: pelo estudo da linguagem como prática social multissemiótica. In: SILVA; DANIEL; et al (Orgs.). A formação de professores de línguas: novos olhares - Volume 2. Campinas, SP: Pontes Editores, 2012.

LEMKE, J. Multimidia Literacy Demands of the Scientific Curriculum. Linguistic and Education 10 (3): 247-271, 2000.

MACHADO, A. R.; CRISTÓVÃO, V. L. L. A construção de modelos didáticos de gêneros: aportes e questionamentos para o ensino de gêneros. Linguagem em (Dis)curso, UNISUL, v.6, número especial, 2006.

MARCUSCHI, L. A. Da fala para a escrita: atividades de retextualização. São Paulo: Cortez, 2001.

Gêneros textuais: definição e funcionalidade. In: DIONÍSIO, A. P.; MACHADO, A. R.; BEZERRA, M. A. (Org.). Gêneros textuais e ensino. 4. ed. Rio de Janeiro: Lucerna, 2005.

2008.

Produção textual, análise de gêneros e compreensão. São Paulo: Parábola Editorial, Gêneros textuais emergentes no contexto da tecnologia digital. In: MARCUSCHI, L. A.;

XAVIER, A. C. (Orgs.) Hipertexto e gêneros digitais. São Paulo: Cortez, 2010, p. 15-80. 
MAYER, R. E. Multimedia learning. Cambridge, UK: Cambridge University Press. (2001).

ROJO, R.; MOURA, E. (Orgs.). Multiletramentos na escola. São Paulo: Parábola Editorial, 2012.

SHIFMAN, L. Memes in digital culture. Massachusetts: MIT Press, 2014.

SOARES, M. Novas práticas de leitura e escrita: letramento na cibercultura. Revista Educação e Sociedade. Campinas, vol. 23, n. 81, p. 143-160, dez. 2002.

ZACHARIAS, V. R. C., Letramento digital: desafios e possibilidades para o ensino. In:

COSCARELLI, C. V. (Org.). Tecnologias para aprender. 1. ed. São Paulo: Parábola Editorial, 2016. p. 15-29.

Recebido em 16/05/2017

Aceito em 01/07/2017

Publicado em 04/06/2017 